Taxes repercussion on FDI in UAE in light of recommendations of IMF

Dr/ Mosaad Mohamed Elgayish

\title{
Taxes repercussion on FDI in UAE in light of recommendations of IMF
}

\section{Mosaad Mohamed Elgayish \\ Vice Dean Faculty of Politics \&Economics, Beni-Suef \\ University, Beni-Suef, Egypt \\ Email address: \\ mosaad2000@eps.bsu.edu.eg \\ "Corresponding author \\ Mobil; 002 - 01288337884}

\section{Abstract}

In its early 2020 report, IMF recommended that the Arab Gulf States, including the United Arab Emirates, need to increase taxes and not to fully rely on oil as a source of income in the country. Therefore, the problem of research has crystallized into the extent to which the tax increase will affect the flow of FDI to the UAE; the multiple regression models was used to find out the determinants that affect the attraction of FDI to the UAE, depending on the world bank data. The model showed the importance of three variables, namely $\mathrm{X} 8$, which expresses the general budget deficit, as it explained 50\%, X4, which expresses On the unemployment rate, where it explained $13 \%$, then $\mathrm{X} 7$, which expresses the current account deficit, as it explained $7 \%$ of the change in inward investment to the UAE respectively, as the importance of Investing in the oil field, as international 
Taxes repercussion on FDI in UAE in light of recommendations of IMF

Dr/ Mosaad Mohamed Elgayish

investment companies are attracted to invest in the extraction of Emirati oil, after adding X5 which represent UAE oil sales, which affected $8.4 \%$ of the GDP Total. The research recommended the need to pay attention to reducing the state's public budget deficit, which increased due to the interest in spending on the infrastructure, and attention must be paid to the need to reduce the unemployment rate and to continue the policy of encouraging domestic and foreign investment as well, and the gap between exports and imports must be reduced and the gap in the balance deficit reduced.

\section{Keywords ${ }^{1}$}

IMF, Taxes, UAE, FDI

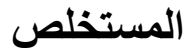

أوصي صندوق النقد الدولي في تقريره مطلع ·. ·. . دول الخليج ومن بينها دولة الامارات العربية المتحدة بضرورة زيادة الضرائب وعدم التعويل الكامل علي فئي

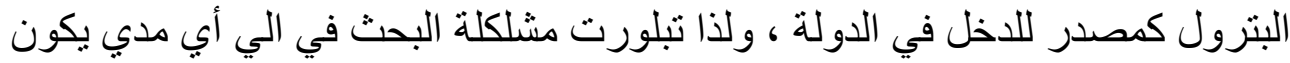

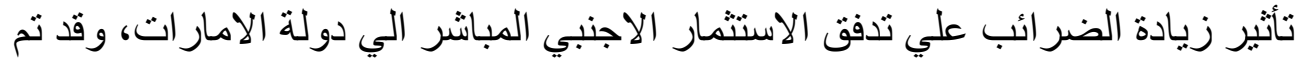

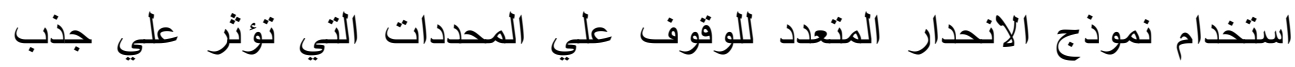

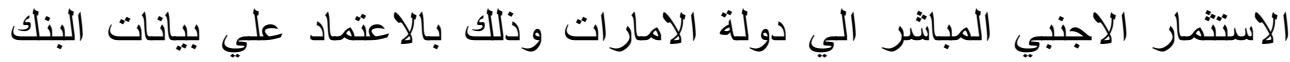

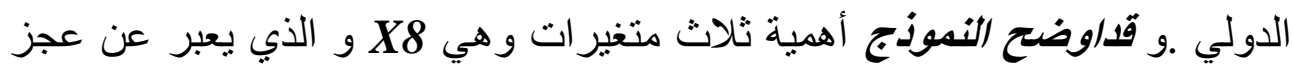

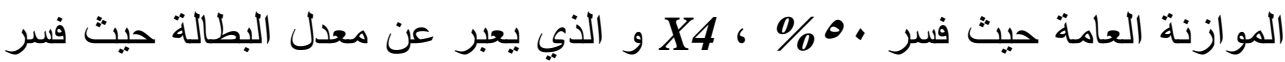

${ }^{1}$ IMF, : International Monetary Fund

UAE: The United Arab Emirates

FDI: Foreign Direct Investment 
Taxes repercussion on FDI in UAE in light of recommendations of IMF

Dr/ Mosaad Mohamed Elgayish

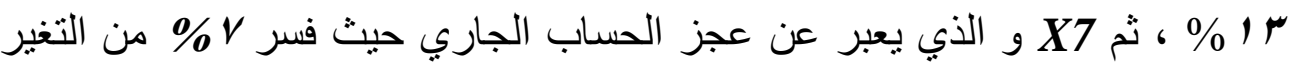

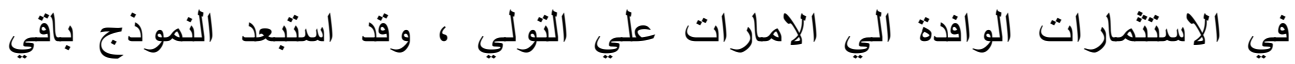

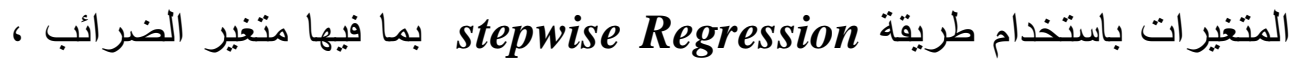
كما اتضح أهمية الاستثمار في مجال النفط حيث تتجذب شركات الاستثمار الدولية للاستثمار في استخر اج النفط الامار اتي وذللك بعد ادخال متغير تطور مبيعات النفال النفا

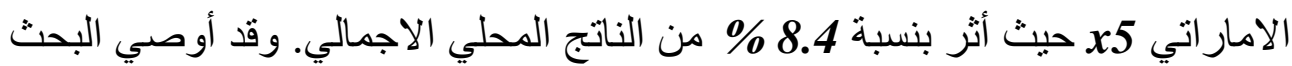

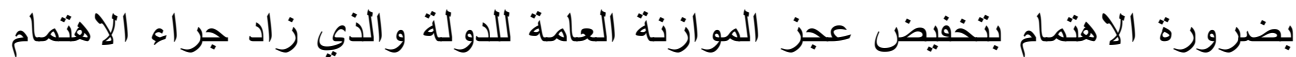

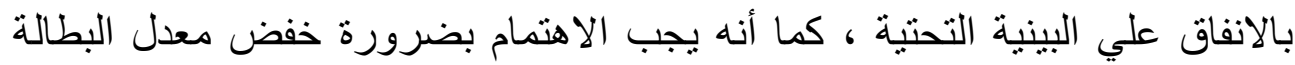

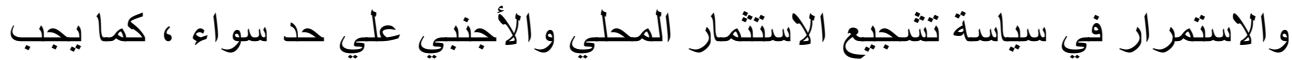

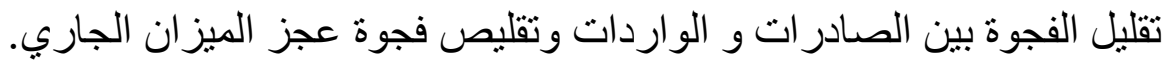

الكلمات المفتاحية

\section{الضر ائب ـ الامارات ـ الاستثمار الاجنبي المباشر - صندوق النقد الدولي}

\section{1- Introduction}

The application of commercial profits tax in the United Arab Emirates began in 2005 at a rate of 14\% [21]. Then Decree-Law No. 7 of 2017 was issued in August regarding Excise Tax, followed by the second decree of Law No. 8 of 2017 regarding value added tax. After that, the excise tax was officially implemented in the last quarter of 2017, which aimed to reduce the consumption of goods harmful to human health and preserve the environment, by imposing a $50 \%$ tax on soft drinks, and $100 \%$ on tobacco products. Then, a value-added tax was imposed, starting from January, 2018, at a rate of $5 \%$ on the 
Taxes repercussion on FDI in UAE in light of recommendations of IMF

Dr/ Mosaad Mohamed Elgayish

import and supply of goods or services [16]. On the other hand, those in charge of implementing the new tax system in the UAE raised many concerns about negative impacts on the economy and business, especially in light of a global economy witnessing a decline in demand and growth rates. The UAE economy is a capitalist economy whose revenues are based on government fees and oil resources in accordance with the constitution, and in which there is less reliance on consumption taxes as fixed sources of tax revenues. The UAE economy also adopts open market policies, and in 2017 there was a decision to implement taxes within the framework of a new strategic vision for the financial management of the state aimed at reducing dependence on oil as a main source of revenue that works to provide sustainable revenues that allow the state to maintain its economic position, the quality of the business environment and invest in it. The International Monetary Fund has recommended not to completely depending on oil as the main source of UAE income. The United Arab Emirates joined the membership of the International Monetary Fund under Federal Decree No. (40) Of 1972, and the state's contribution amounted to 752.5 million SDUs in 2010, equivalent to $3,847.5$ billion dirhams, or $0.32 \%$. The state's voting power in the Council management rate is $0.33 \%$ [10]. The foreign direct investment report mentioned that the Emirate of Dubai in 2018 contributed to foreign direct investment in creating jobs, as it reached about 25,000 new jobs 
Taxes repercussion on FDI in UAE in light of recommendations of IMF

Dr/ Mosaad Mohamed Elgayish

in 2018 , an increase of $77 \%$ compared to 14,065 in 2017 , which placed Dubai in the ninth place globally in terms of Creating new job opportunities through foreign direct investment. In addition, the total assets of foreign direct investment in the UAE amounted to 129.9 billion dollars at the end of 2017, a growth of $8.7 \%$ compared to 2016, according to the official Emirates News Agency [18].

\section{2- Research problem - its importance - its limitations}

The foreign investor is apprehensive about increasing the taxes imposed on him by the receiving country for foreign direct investment, because it directly leads to a decrease in his profits, which he sought to maximize and leave his country in pursuit of achieving the maximum possible profit, and hence the problem of research in light of the recommendation of the International Monetary Fund to the Gulf states of the necessity Raise tax rates. Therefore, the problem of research was to find a mechanism for the effect of increasing taxes on the flow of foreign direct investment to the United Arab Emirates, and to determine the extent of the impact of taxes and the strength of their influence on attracting foreign direct investment to the UAE, during the period from 1990 to 2019. The importance of the research stems from its being looking into a very important topic, especially at a time when the revenues of all countries of the world have decreased due to the Corona crisis, which affected the revenues of all countries of the world, both developed and developing, and 
Taxes repercussion on FDI in UAE in light of recommendations of IMF

Dr/ Mosaad Mohamed Elgayish

therefore countries had to rely on various sources of Income, especially after the drop in oil prices after the decrease in global demand for it, hence the recommendation of the International Monetary Fund that new taxes should be increased and more over impose new taxes in the UAE that would help diversify sources of revenue and not rely on one source of income in the country.

\section{3- Research hypothesis and method}

The research assumes that taxes are one of the determinants of foreign direct investment, such as the state budget deficit, the extent of the current balance, the inflation rate, the unemployment rate, the economic growth rate, international reserves of hard currencies and oil, especially for oil-producing countries. The inductive approach was used where the multiple regression model was used to find out the determinants that affect the attraction of foreign direct investment to the UAE, depending on the data of the World Bank, and the ratio of foreign direct investment to net inflows $\boldsymbol{Y}$ was taken as \% of $\boldsymbol{G D P}$ and a set of variables Independent, which is believed to have a differential effect on the proportion of foreign direct investment net inflows in percent of GDP, which is $\boldsymbol{X} \boldsymbol{1}$ tax rate (tax rate as a percentage of commercial profits), $\boldsymbol{X} \mathbf{2}$ economic growth rate (measured by growth in per capita GDP in percent per year) ), $\boldsymbol{X} \mathbf{3}$ the inflation rate (the annual GDP deflator in\%), $X \boldsymbol{4}$ the unemployment rate (a percentage of the total workforce), $X \mathbf{5}$ the 
Taxes repercussion on FDI in UAE in light of recommendations of IMF

Dr/ Mosaad Mohamed Elgayish

oil sales of the UAE, $\mathbf{X} \boldsymbol{6}$ the total international reserves of hard currencies (in billion dollars - including gold at current US dollar prices) , $\boldsymbol{X} 7$ current account to GDP, $\boldsymbol{X} \boldsymbol{8}$ the public budget deficit as a percentage of GDP.

\section{4- Previous studies}

In a study of Basi 1963, it showed that political stability has a great impact on attracting foreign direct investment and that it is the primary determinant of US investments in developing countries [2]. In a study conducted by Schneider and Frey 1985, on a group of developing countries for the years (1976, 1979, and 1980), it showed that political instability has a negative correlation with foreign direct investment [13]. D.J. Lecraw 1991 also showed in his study that economic reform is a positive factor in attracting foreign direct investment. It also showed that foreign direct investment to exports is adversely affected by the relative changes of the exchange rate. . [4] Moreover a study of Akhter 1993 also showed that the most important determinants of foreign direct investment are infrastructure, market size, human capital, proximity to major markets, and degree of openness to the outside world, the exchange rate, tax incentives, political stability, and monetary policies. [1]. The study of Samiha Fawzi, 2002 dealt with the policies responsible for the low level of investment in Egypt, during the 1990s, despite giving opportunities to the private sector since the implementation of the economic reform program, the response of the private sector 
Taxes repercussion on FDI in UAE in light of recommendations of IMF

Dr/ Mosaad Mohamed Elgayish

remained limited in relation to the development goals that were sought in terms of raising growth rates [12]. Also Employment and increased integration in global markets, the complexity of tax administration, the shortcomings and slow of dispute resolution mechanisms and the high cost of the labor component as a result of its low productivity, the high value of social insurance, and the difficulty of exporting due to the exaggeration in the exchange rate are all reasons that led to the low level of investment in Egypt. . [11]

The Development Studies Sector in the Egyptian Council of Ministers also dealt with a study entitled International Experiences to Improve the Investment Climate in October 2004. The experiences of 23 developing and developed countries were studied to determine the determinants of investment and other forces affecting investment activity in order to succeed in this field to improve the investment climate. The study concluded with some conditions to improve the investment climate, such as dealing with economic instability, by controlling inflation rates and reducing the levels of the state budget deficit, taking into account the facilitation of administrative procedures and the improvement of communication systems, support for political stability As it is an important requirement for establishing a safe environment for investments, because the political role plays an important role in shaping the economic climate in general and the investment climate in particular[14]. The World Investment Report 2009 also dealt 
Taxes repercussion on FDI in UAE in light of recommendations of IMF

Dr/ Mosaad Mohamed Elgayish

with the importance of foreign direct investment for China and how foreign investment played a major role in achieving a boom in the Chinese economy. In 1999, China sought to establish about 315,000 foreign investment projects with a contractual value of about $\$ 600$ billion, and the volume of investment reached the foreign flow to the Chinese economy reached 72,715 million dollars in 2006, and in 2008 it increased significantly to 108,312 million dollars. In addition, the volume of Chinese foreign trade reached in 2003 more than 850 billion US dollars; it ranked fourth after the United States, Germany and Japan, and before Britain and France. In 2004, Chinese foreign exchange reserves exceeded 400 billion US dollars, second only to Japan. The Chinese economy shifted from a planned economy to a socialist economy at the beginning of this century [19]. Finally The study of Nooria Abd Mohammad, 2012 examined the impact of foreign direct investment on the future of Arab local investment and indicated that developing countries, including the Arab Gulf states, are working hard to attract foreign investment, by excluding restrictions on the movement of capital and granting generous incentives to foreign investors, the study also attributed the increase in foreign direct investment to the Gulf countries to an increase in oil exports, as well as the importance of modernizing the legislative systems that the Arab Gulf countries have implemented to attract foreign investment. . [9] 
Taxes repercussion on FDI in UAE in light of recommendations of IMF

Dr/ Mosaad Mohamed Elgayish

\section{5- International Monetary Fund}

IMF was established after the Great Depression of 1929, as was the case with many international economic organizations whose purpose was to reform what was corrupted by the disaster of the Great Depression that afflicted USA. The Great Depression consequences extended to the rest of the world from bankruptcy to thousands of banks, and lower prices of agricultural products, especially for less than the cost, Factories were also suspended, and the movement of ports was disrupted. As a result of all this, there was widespread unemployment. In addition to the decrease in the degree of confidence in paper money which led to an increase in the demand for gold, which led to the abandonment of the gold standard. The value of each currency was determined by a fixed amount of gold, and because that rule was no longer applicable, there was no confidence in the value of paper money and the exchange of paper money became difficult for countries that were following the gold standard. As a result of countries hoarding gold and gold coins, the problem of deflation in the monetary exchange of living between countries increased, which resulted in a decrease in living standards. Many international conferences were held during that period in each country separately to treat these problems, but all of them were in failure. Hence, thinking about international conferences in which all parties participated to find common solutions that serve the international community. The American Harry Dexter White 
Taxes repercussion on FDI in UAE in light of recommendations of IMF

Dr/ Mosaad Mohamed Elgayish

presented a proposal. The Englishman, John Maynard Keynes, proposed that they shared the idea of finding a permanent international cooperation organization to solve these problems instead of occasional international meetings, Hence the thinking about establishing IMF [3].

IMF is a specialized international organization of the United Nations. It was established by the Bretton Woods International Treaty in 1945 with the aim of strengthening the health of the global economy. The idea of establishing IMF came in July 1944 during a United Nations conference held in Bretton Woods, New Hampshire, USA, where it was agreed among representatives of forty-five countries to set a general framework for economic cooperation among these countries with the aim of avoiding a recurrence of the failure of economic policies, which was a major cause The disaster of the Great Depression in 1929. IMF is an international organization with 189 member states, and it aims to improve the safety of the global economy, enhance global monetary cooperation, ensure financial stability, facilitate global trade, increase employment opportunities, continuous economic growth, reduce poverty throughout the world and stabilizing exchange rates and balanced growth in international trade. IMF discusses the effects of the economic policies of each country at the national, regional and global levels. It also approves or opposes the loans it provides to help member states to solve temporary problems in their balance of payments [5]. 
Taxes repercussion on FDI in UAE in light of recommendations of IMF

Dr/ Mosaad Mohamed Elgayish

IMF is responsible to the governments of its members represented in the Executive Council, which in turn monitors the daily activities of the Fund, in addition to the Director General and Deputies, under the management of the supreme authority of the Board of Governors, which is composed of the finance ministers of all member states [6]. Each member state must pay a share or a contribution that is a specific amount of money, which is equivalent to membership subscription, and is also the store through which aid is provided to the member state that needs assistance in the future, and the greater the share of the member state, the greater its ability to borrow when needed, and the member's share determines its voting power within the Fund's Board, and the International Monetary Fund itself determines the amount of the state's share, through its analysis of the country's joint wealth and its economic performance, and accordingly the quota is determined for the next five years [3]. The United Arab Emirates joined IMF under Federal Decree No. (40) Of 1972. [10]. and the contribution of the United Arab Emirates is about 752.5 million SDUs, equivalent to $3,847.5$ billion dirhams That is, at a rate of $0.32 \%$, and the voting power of the state in its board of directors is $0.33 \%$ [8].

The report of $\boldsymbol{I M F}$ at the beginning of the year 2020 indicated that there is a danger facing the Arab Gulf States in the coming period, Arab Gulf countries debts increased from 100 billion $\$$ in 2014 to $\$ 400$ billion $\$$ in 2018 . The Gulf States are on the right 
Taxes repercussion on FDI in UAE in light of recommendations of IMF

Dr/ Mosaad Mohamed Elgayish

track, but they need to accelerate financial reforms. The report also indicated that projects to diversify the economy are not sufficient, State expenditures must be reduced and financial systems approved that increase non-oil revenues, especially taxes, because the impact of the decline in oil and gas revenues has not been fully compensated for, the expected speed and volume of financial control measures in most Gulf countries has not enough to stabilize its fortune [7]. The report also indicated that all the Gulf Cooperation Council countries are aware of the constant nature of the challenge they face, that the financial wealth of the Gulf countries will be negative by the year 2034 and will turn into indebted countries.

\section{Taxes}

About fifty years ago, the revenues of the United Arab Emirates have been concentrated in its revenues from government fees and oil sources, like the oil countries and the Arab Gulf States, and there is less reliance on consumption taxes as stable sources of tax revenues. Although the UAE economy is a capitalist economy based on open market policies, its constitution states that public revenues consist of taxes, fees and revenues [17]. In 2017, the UAE began implementing its tax system amid fears of its negative effects on the economy and business, especially in light of a global economy experiencing a contraction in demand and a decline in growth rates. The idea of implementing taxes came within the framework of a new strategic vision for the state's financial 
Taxes repercussion on FDI in UAE in light of recommendations of IMF

Dr/ Mosaad Mohamed Elgayish

management with the aim of reducing dependence on oil as a primary source of revenue and providing sustainable revenues that would help the state maintain its economic position, in addition to providing an attractive investment climate for investments, especially foreign investments. In August 2017, the first tax law was issued, which is Decree-Law No. 7 of 2017 regarding selective tax, and then Decree-Law No. 8 of 2017 regarding value-added tax, in the framework of commitment to what has been agreed upon between the countries of the Gulf Cooperation Council. The selective tax, which aims to reduce the consumption of goods that are harmful to human health or the environment, has officially started to be applied through the imposition of a $50 \%$ tax on soft drinks and $\mathbf{1 0 0 \%}$ on tobacco products and energy drinks, and this was followed by the imposition of a value-added tax, starting from January 1, 2018, 5\% on the import and supply of goods or services. The application of the tax system in the United Arab Emirates required the development of integrated legislative foundations to ensure the proper implementation of the tax system, through the Ministry of Finance issuing legislation and policies for preparing the legal frameworks for the implementation of value-added tax and excise tax. The authority has also put in place appropriate mechanisms to implement these legislations that clearly defined all mutual obligations between the authority and taxpayers, which helped to create an appropriate environment that works in accordance with standards of governance and transparency, as well 
Taxes repercussion on FDI in UAE in light of recommendations of IMF

Dr/ Mosaad Mohamed Elgayish

as the authority to implement a fully electronic tax system that encourages those subject to tax to self-submit accompanied by easy procedures [20].

\subsection{Excise tax}

Excise tax is an indirect tax that is imposed on the consumption of goods harmful to human health or harmful to the environment. It is called selective goods such as soft drinks, on which a tax is imposed at 50\%. It is also imposed on energy drinks, tobacco and its products at a rate of $\mathbf{1 0 0 \%}$. It also includes drinks sweetened with added sugar by $\mathbf{5 0 \%}, \mathbf{1 0 0 \%}$ electronic smoking tools and devices. , The UAE government applied excise tax in the last quarter of 2017 [21].

\subsection{Value Added Tax}

The value-added tax is the same as the excise tax, as it is an indirect tax, and it is a type of consumption tax that is applied in more than 150 countries of the world and is imposed on most goods and services that are bought or sold at every stage of the production process, where companies collect this tax and calculated, it in the interest of the government from the final consumer who bears it. The Gulf States adopted a 5\% rate for imposing it, as both the UAE and Saudi Arabia applied it since the beginning of January 2018. The new tax system helped the United Arab Emirates to pump new revenues that would help create new job opportunities through the establishment of 
Taxes repercussion on FDI in UAE in light of recommendations of IMF

Dr/ Mosaad Mohamed Elgayish

investment projects, in addition to reducing the level of consumption of products harmful to health and the environment, and the companies operating in the country developed their accounting and technical systems, which contributed positively to the performance of these companies, as the business sectors have applied advanced systems to maintain comprehensive electronic accounting records for their activities, and their balance sheets accurately and clearly. However, the overall demand of the UAE has been affected by corporate mergers and structural reforms, which included large entities linked to the government and large commercial banks, as well as the state of public finance. Therefore, the matter requires a new mechanism to benefit from new growth engines separate from oil prices, which in turn requires the adoption of some measures and policies that one of the most important of these is reducing the role of the public sector, in order to support productivity growth and promote diversification of activity, it will be necessary to create conditions for fair competition between governmentrelated entities and private sector participants. Another priority is strengthening the enabling environment for small and medium enterprises and building on recent reforms to encourage foreign direct investment. Also, it is necessary to modernize the labor market with the aim of achieving sustainable growth led by the private sector while achieving the authorities 'goal of increasing the employment of national workers in the private sector. It also 
Taxes repercussion on FDI in UAE in light of recommendations of IMF

Dr/ Mosaad Mohamed Elgayish

requires enhancing competitiveness and reducing dispersion in the labor market in order to ensure that skills are directed towards their most productive uses. At the same time, the authorities should build on their existing efforts to ensure the UAE continues to attract and retain skilled expats. Also, working to strengthen the financial markets would support the investment process. It is worth noting here the vital role that the UAE Central Bank has played in its efforts to strengthen the financial system, including its move to the application of "Basel 3" standards [22].

\section{Determinants of foreign direct investment in the .}

\section{Emirates}

Global economic blocs and international economic organizations such as the World Trade Organization, the emergence of the concept of privatization, the establishment of free zones for global trade, the transition to the era of technology revolution and international competition, the liberalization of markets for goods, services and capital, the emergence of economic phenomena such as unemployment, inflation and the intensification of economic and trade conflicts between various countries and blocs, then slowing rates Economic growth and the emergence of economic crises, such as the Asian crisis in 1997 or the oil crisis in 1998, all these global economic changes and developments were reflected, directly and indirectly, on the UAE economic situation, then the second Gulf crisis of 1990 followed, and then the 
Taxes repercussion on FDI in UAE in light of recommendations of IMF

Dr/ Mosaad Mohamed Elgayish

liberation of Kuwait, with their clear negative repercussions. On the economy of the $\mathrm{GCC}^{2}$ countries, including the UAE, due to the fluctuation that occurred in oil prices in the global market and its impact on the Gulf economy in particular. The UAE economy was affected and this was evident through economic and financial indicators, for example the balance of trade and the balance of payments were affected, oil exports decreased, the general budget deficit increased, and economic growth rates decreased in various economic sectors. It shows the extent to which the UAE economy depends on oil due to the lack of seriousness towards finding a diversified production base that mitigates the impact of fluctuations and fluctuations in oil prices on the national economy [21].

\subsection{Tax rate $\mathrm{X} 1$}

The UAE imposed a tax on commercial profits, which is limited to between $14 \%$ and $15 \%$ over the past fifteen years (according to World Bank data, 2020)

${ }^{2}$ Gulf Cooperation Council 
Taxes repercussion on FDI in UAE in light of recommendations of IMF

Dr/ Mosaad Mohamed Elgayish

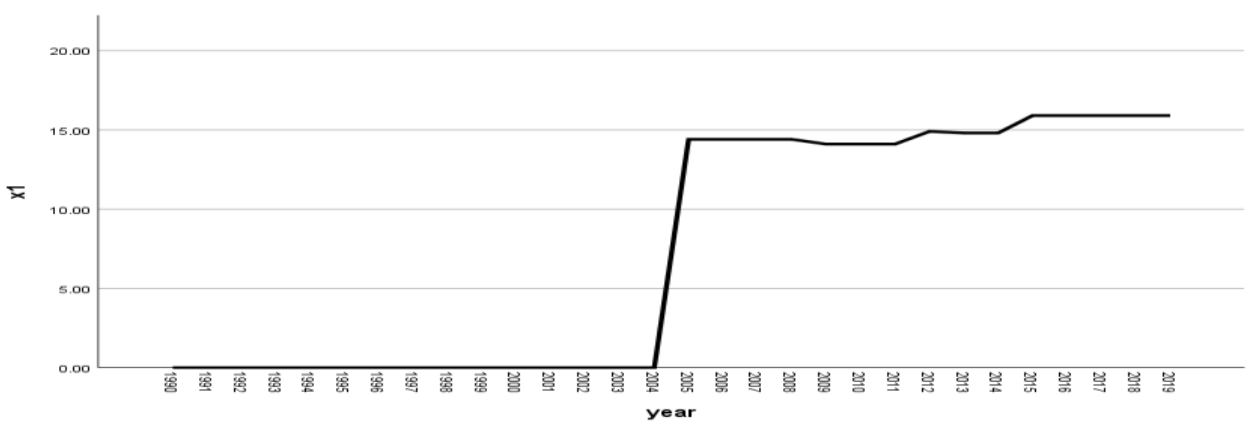

Tax rate - tax rate as a percentage of commercial profits https://data.albankaldawli.org/indicator

\subsection{Economic growth rate $\mathrm{X} 2$}

The indicator per capita gross domestic product in percent annually is used to express the rate of economic growth. It is noted that in 1990 despite the sharp developments that occurred in the regional and international arena, the UAE economy achieved good growth rates in various economic sectors. The per capita gross domestic product was $11.6 \%$, and this growth is due to the non-oil commodity sectors, after the decline in oil prices during that period. However, after that, in the years 1991 to 1993 , it recorded a negative growth, then it became 1.25 in 1994, but it recorded negative proportions in the following years until 2010, then it achieved a positive ratio in 2011, 2012, recording 2.19 and 2.26 respectively, then 0.21 in 2018 . 
Taxes repercussion on FDI in UAE in light of recommendations of IMF

Dr/ Mosaad Mohamed Elgayish

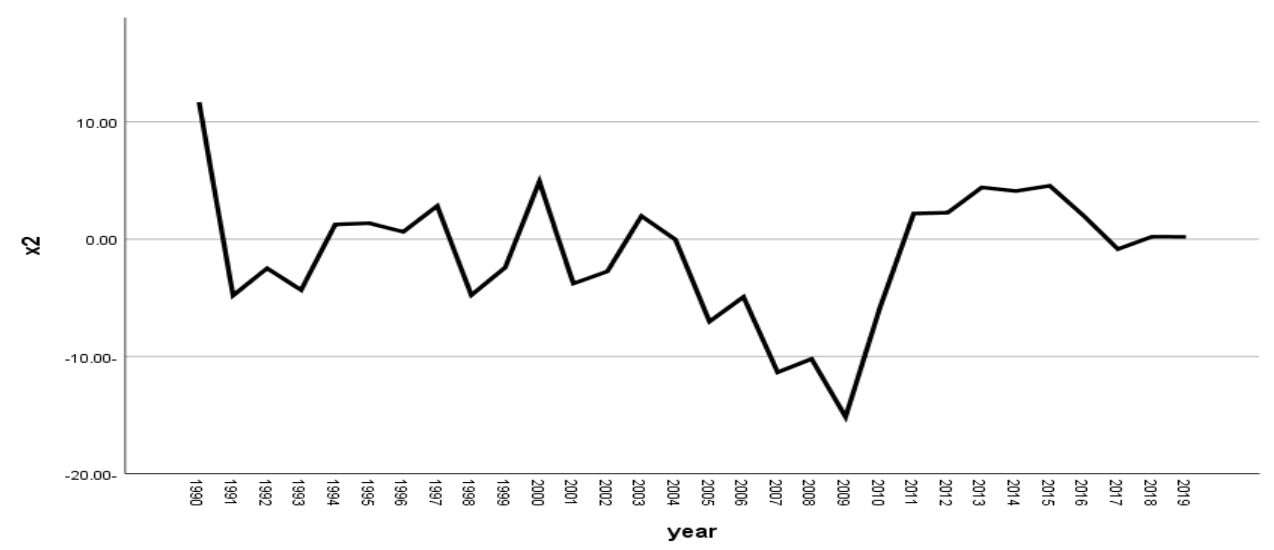

X2 Economic growth rates - a measure of growth in per capita GDP in percent annually

https://data.albankaldawli.org/indicator

\subsection{Inflation rate X3 (annual \% GDP deflator)}

By reviewing the inflation rate, it could be notice that it reached $3.30 \%$ in 1990, and then declined sharply in the following years until 1995, reaching $3.91 \%$, then $5.77 \%$ in 1996 . Then it reached $8.44 \%$ in 1999 , then $11.46 \%$ in 2000 . Then it reached its peak in 2008, when it reached $18.53 \%$. Then it continued to decline from 2012 to 2017 , and then rose again in 2018, recording $7.8 \%$. 
Taxes repercussion on FDI in UAE in light of recommendations of IMF

Dr/ Mosaad Mohamed Elgayish

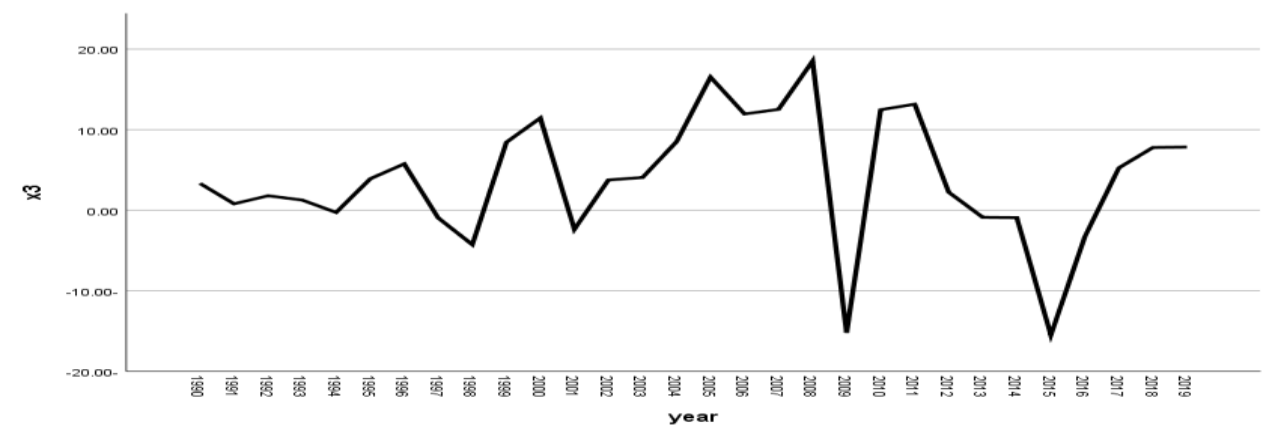

X3 Inflation rate (annual\% GDP deflation factor-

https://data.albankaldawli.org/indicator

\subsection{Unemployment rate $\mathrm{X} 4$ percentage of the total workforce}

The unemployment rate ranged between $1.58 \%$ in 1990 and $1.80 \%$ in 1995 , then the unemployment rate increased to $2 \%$ in 2000 to $2.99 \%$ in 2003. Then it exceeded $3 \%$ in 2004, 2005, where it recorded $3.18 \%$ and $3.12 \%$, respectively, until it decreased to $2.23 \%$ in 2018.

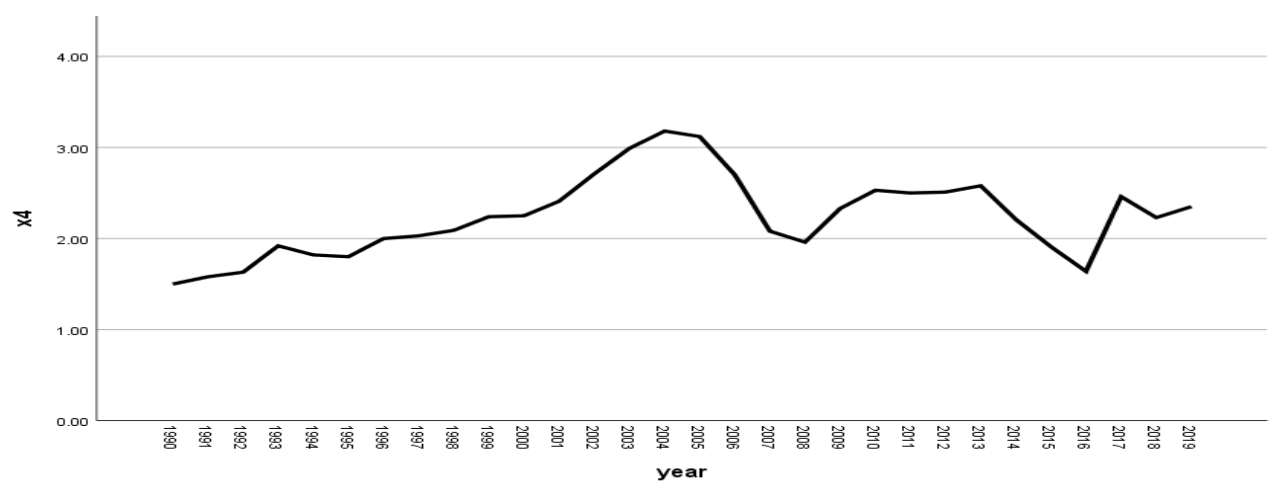

Unemployment rate - a percentage of the total labor forcehttps://data.albankaldawli.org/indicator 
Taxes repercussion on FDI in UAE in light of recommendations of IMF

Dr/ Mosaad Mohamed Elgayish

The multiple regression model showed that the ratio of net inflows of foreign direct investment was taken as a percentage of GDP, and the rest of the variables were explained variables. All the variables (X1, X2, X3, X4, X5, X6, X7, and X8) were entered into [SPSS] and the Unit Root Test Augmented DickeyFuller Test Equation and Phillips-Perron test statistic were all stable at the level and by inputting the variables $Y, X 1, X 2, X 3$, $X 4, X 5, X 6$ and $X 7$ on SPSS using Stepwise regression

It is a multiple regression model

$Y=-10.022+2.29 X 4+8.394 X 5$

It is noted that the model is significant, and the explanatory variables $X 4, X 5$, are significant, with a determination factor of 74.8\%, and that the model does not suffer from self-correlation using the Breusch-Godfrey Serial Correlation LM Test: the model does not suffer from the problem of variability instability using the Heteroskedasticity Test: ARCH, And the rest follow the normal distribution HISTOGRAM-NORMALITY TEST, and the model parameters are consistent with economic theory.

\subsection{X5 UAE oil sales}

The factor $X 5$ of the UAE's sales of crude oil is one billion barrels is positive, that means the increase in the UAE's sales of crude oil by one billion barrels leads to an increase in the proportion of foreign direct investment by $8.394 \%$ of the gross domestic product. The following figure depicts the development 
Taxes repercussion on FDI in UAE in light of recommendations of IMF

Dr/ Mosaad Mohamed Elgayish

of the average UAE sales of oil in billion barrels per year, as it recorded 0.83 in 1990 , then 0.68 in 1995 , then increased to 0.80 , then sales increased again in 2005 to 0.88 , then increased to 0.97 in 2014 and then to 0.94 in 2018 .

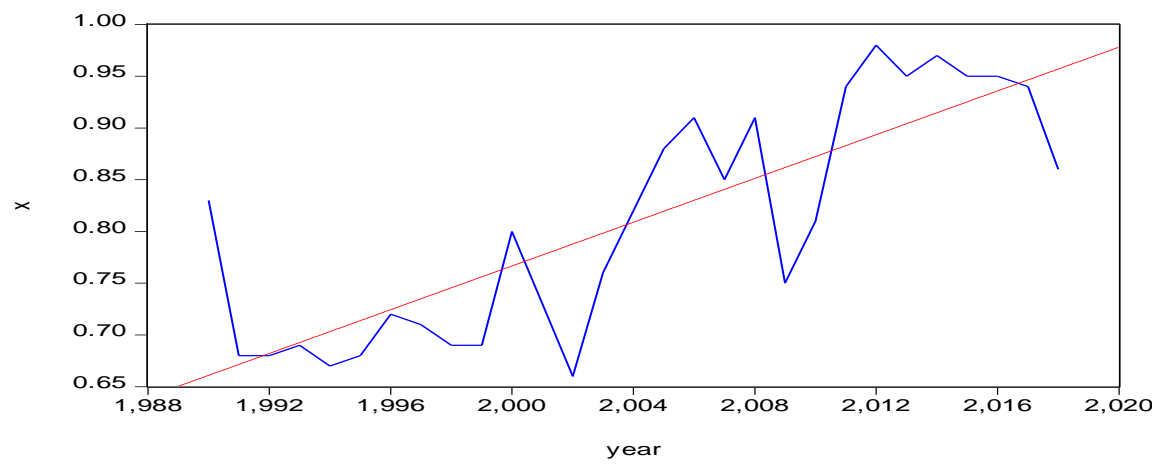

X5 - UAE oil sales- https://data.albankaldawli.org/indicator

\section{V. $\quad$ X6 Total international Reserves}

International reserves of hard currencies recorded successive increases, as they were 4.89 billion dollars in 1990, then they reached 13.63 billion dollars in 2000, 32.78 billion in 2010, until they reached 99.5 billion in 2018 .

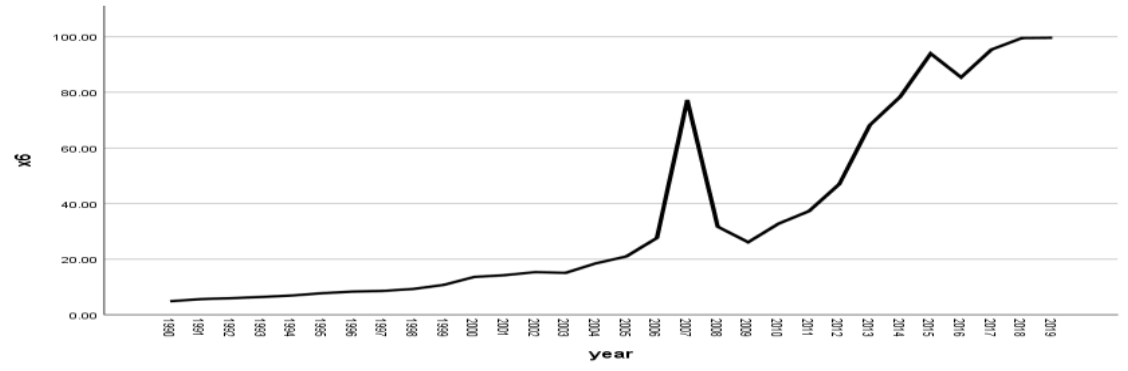

(In billion dollars - including gold in current US dollar prices) https://data.albankaldawli.org/indicator 
Taxes repercussion on FDI in UAE in light of recommendations of IMF

Dr/ Mosaad Mohamed Elgayish

\subsection{X7 Current account to GDP}

Current account as \% of GDP volatility during a study period, as shown in the following figure

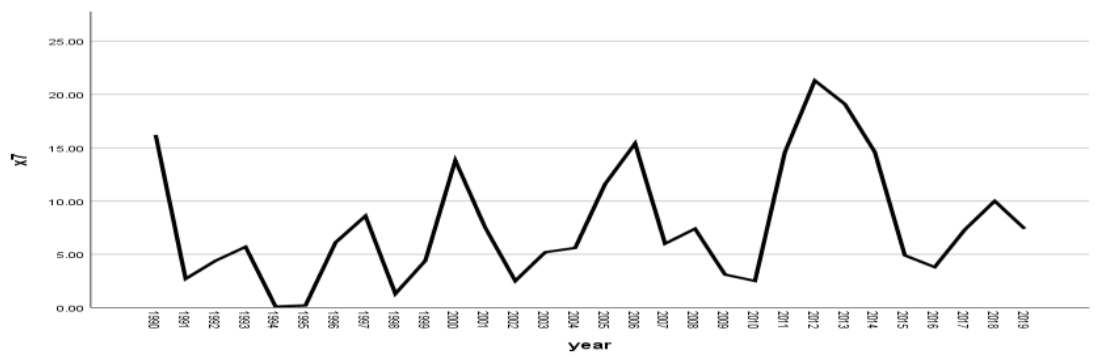

\section{X7 current accounts to GDP}

https://ar.tradingeconomics.com/united-arab-emirates/current-accountto-gdp

\section{8 $\quad X 8 \quad$ Public budget deficit}

By inserting $X 8$ and adding it to the rest of the study variables on the spss program, a stepwise regression method was used, and the result was as follows:

\section{$Y=-0.647+0.164 X 8+1.855 X 4-0.124 X 7$}

Where the previous model illustrated the importance of three variables, namely, $\boldsymbol{X} 8$, which expresses the general budget deficit

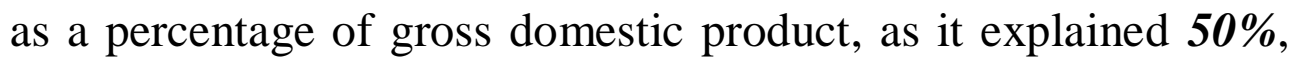
and $X 4$, which expresses the unemployment rate as a seminal proportion of the labor force in the UAE, as it explained $13 \%$ of the change in inbound investment To the United Arab Emirates, then $X 7$, which expresses the current account, as it explained $\mathbf{7 \%}$ 
Taxes repercussion on FDI in UAE in light of recommendations of IMF

Dr/ Mosaad Mohamed Elgayish

of the change in investment coming to the UAE, and in total, the three variables explained about $\mathbf{7 0 \%}$ of foreign investment expenditures coming to the UAE, and there is $\mathbf{3 0 \%}$ due to The rest of the variables. The model excluded the rest of the variables using the stepwise regression method. This is due to the strong correlation between some variables.

It is noted that the model is significant, and the explanatory variables $X 8, X 4, X 7$ are significant, and the model does not suffer from self-correlation using the Breusch-Godfrey Serial Correlation LM Test, and the model does not suffer from Contrast instability problem with Heteroskedasticity Test: ARCH and residues follow a normal distribution

\section{HISTOGRAM-NORMALITY TEST}

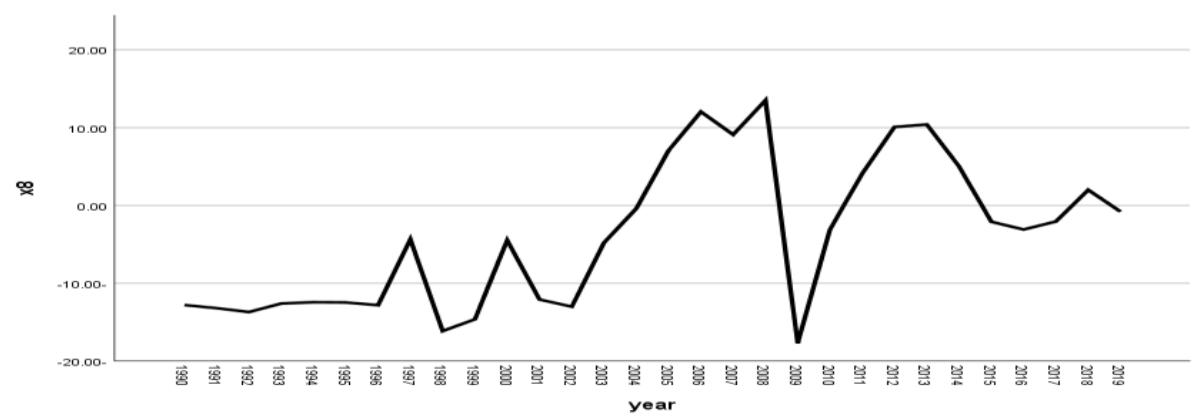

X8 the public budget deficit as a percentage of GDP

https://ar.tradingeconomics.com/united-arab-emirates/government-budget

\section{Research summary}

After the issuance of IMF report in early 2020 and the direct warning contained in it to the Arab Gulf states after the complete 
Taxes repercussion on FDI in UAE in light of recommendations of IMF

Dr/ Mosaad Mohamed Elgayish

dependence on oil as a source of income and the need to search for other alternatives, including increasing taxes. Therefore, the research focused on studying the effect of increasing taxes on the flow of foreign direct investment to the United Arab Emirates in light of the recommendations of the IMF. After reviewing the determinants of foreign direct investment for the United Arab Emirates and including taxes, and after using the multiple regression model referred to above, it was found that:

\subsection{Search results:}

1. The model excludes taxes from affecting the flow of foreign direct investment into the United Arab Emirates

2. The model illustrated the importance of the UAE oil determinant $\mathbf{X 5}$ in attracting foreign direct investment to the UAE and that it is an attraction factor for many foreign investments to the UAE.

3. It shows the importance of the determinant of the unemployment rate $\boldsymbol{X} \mathbf{4}$, which expresses the unemployment rate, as explain $\mathbf{1 3 \%}$

4. It also shows the importance of $X 7$, which reflects the current account as it explained $7 \%$ of the change in investments coming to the UAE on the assumption

5. The model clarified the importance of the specific deficit of the state's public budget, as it explained 50\% of the changes in the volume of foreign direct investment flow to the UAE. 
Taxes repercussion on FDI in UAE in light of recommendations of IMF

Dr/ Mosaad Mohamed Elgayish

\subsection{Research recommendations}

1. Increasing taxes does not affect the attraction of foreign investment to the Emirates, especially since the types of taxes imposed by the Emirates, such as excise tax, or value-added tax are imposed on goods harmful to the health of individuals

2. The need to pay attention to reducing the state's public budget deficit, which increased as a result of spending on the infrastructure

3. Attention must also be paid to the need to reduce the unemployment rate and to continue the policy of encouraging domestic and foreign investment alike

4. The gap between exports and imports should be reduced, and the current balance deficit gap should be reduced.

5. The need to diversify the sources of national income of the United Arab Emirates, whether by imposing taxes or other sources of income, and not fully relying on oil, especially with the dependence of many countries in the world on renewable energy sources, even if the world's dependence on renewable energy sources does not full substitute for the use of oil in particular in the petrochemical field. 
Taxes repercussion on FDI in UAE in light of recommendations of IMF

Dr/ Mosaad Mohamed Elgayish

\section{References}

1. Akhter 1993, Foreign Direct Investments In Developing Countries: The Openness Hypothesis And Policy Implications, Article (PDF Available) in The International Trade Journal 7 (6): 655-672 • December 1993 with 76 Reads, pp. 662-665

2. Basi, R.J (1963), Determents of United States, private direct investments in foreign counties, Kent state university, Bureau of Economic and Business Research, 1963.pp. 12-16

3. David Driscol, 1991, translated by Muhammad Hassan Yusuf, What is the International Monetary Fund? Revised edition, 1992, original copy can be obtained from external relation department, publication services, international monetary fund, 70019, the street, N.W, D.C 20431-0. Pp. 5-10

4. D.J, Lecraw (1991), "performance of transnational corporations in less developed counties".pp. 163-165

5. International Monetary Fund, Finance and Development Journal, The Growth Dilemma, March 2017

6. International Monetary Fund, Global Challenges - Scientific Solutions, www.imf.org

7. International Monetary Fund, 2020, The future of oil and fiscal sustainability in the GCC region, Middle East and Central Research Department, No. 20L01, p-z, p2, p21

8. International Monetary Fund - Official Website -https: //www.imf.org/ar/News/Articles/2019/05/02/pr19138-uae-imf-staffconcludes-visit-to-the-united-arab -emirates

9. Nooria Abd Mohammed, 2012, the effect of foreign investment in the Arabic local investment Future - An Analytical Measurement study for some of the Arabic Gulf States for the Period from 19922010, St Cements university, Mat No 16449, pp.- 16-20. 
Taxes repercussion on FDI in UAE in light of recommendations of IMF

Dr/ Mosaad Mohamed Elgayish

10. Official Website - Ministry of Finance - United Arab Emirates https://www.mof.gov.ae/en/StrategicPartnerships/strategicInterPartn ers/Pages/WorldBank.aspx

11. Rida Abdel Salam, Determinants of Foreign Direct Investment in the Age of Globalization, a comparative study of the experiences of East and Southeast Asia and Latin America with application to Egypt, Alexandria, University House, 2002, p.83

12. Samiha Fawzi 2002, the Egyptian Center for Economic Studies (ECES), Investment Policies and the Unemployment Problem in Egypt, Working Paper No. (68) May 2002, p. 12, p. 13

13. Schneider, F and B.S Frey (1985) Economic and political determents of foreign direct investment, Wald development, 13 Feb. pp. 161175

14. The Council of Ministers, Information and Decision Support Center, Development Studies Sector, International Experiences to Improve the Investment Climate, October 2004, pp. 16, 17

15. The Council of Ministers, Information and Decision Support Center, Development Studies Sector, International Experiences to Improve the Investment Climate, October 2004, P16

16. The official portal of the UAE government, taxes, https://u.ae/enae/information-and-services/finance-and-investment/taxation

17. The Constitution of the United Arab Emirates issued in 1971, including its amendments until 2009, Article 126, p. 24

18. United Nations conference on trade and Development, UNCTAD, World investment report 2020, international production beyond pandemic, pp.44

19. World Investment Report 2009, United Nations, United Nations Conference on Trade and Development, p. 249 
Taxes repercussion on FDI in UAE in light of recommendations of IMF

Dr/ Mosaad Mohamed Elgayish

20. Federal Tax Authority, www. Tax.gov.ae

21. https://data.albankaldawli.org/indicator/IC.TAX.TOTL.CP.ZS?locati ons $=A E \&$ view $=$ chart .

22. IMF experts conclude a visit to the United Arab Emirates, https:/ www.imf.org/ar/News/Articles/2019/05/02/pr19138-uae-imfstaff-concludes-visit-to-the

united-arab-emirates 
Taxes repercussion on FDI in UAE in light of recommendations of IMF

Dr/ Mosaad Mohamed Elgayish

\section{Attachments}

\begin{tabular}{|c|c|c|c|c|c|c|c|c|c|c|}
\hline \multicolumn{11}{|c|}{ Statistics } \\
\hline & & $\mathrm{y}$ & $\mathrm{x} 1$ & $\mathrm{x} 2$ & $\mathrm{x} 3$ & $\mathrm{x} 4$ & $\mathrm{x} 5$ & $\mathrm{x} 6$ & $\mathrm{x} 7$ & $\mathrm{x} 8$ \\
\hline \multirow[t]{2}{*}{$\mathrm{N}$} & Valid & 30 & 30 & 30 & 30 & 30 & 30 & 30 & 30 & 30 \\
\hline & $\begin{array}{l}\text { Missin } \\
\mathrm{g}\end{array}$ & 0 & 0 & 0 & 0 & 0 & 0 & 0 & 0 & 0 \\
\hline \multicolumn{2}{|c|}{ Mean } & 1.9173 & 7.4633 & $-1.2080-$ & 3.9337 & 2.2420 & 5.4980 & 35.7587 & 7.7767 & $-3.8483-$ \\
\hline \multicolumn{2}{|c|}{ Std. Deviation } & 2.04969 & 7.60891 & 5.48804 & 7.91099 & .44008 & 3.05345 & $\begin{array}{r}33.6249 \\
0\end{array}$ & 5.63411 & 9.51284 \\
\hline \multicolumn{2}{|c|}{ Minimum } & $-1.17-$ & .00 & $-15.15-$ & $-15.48-$ & 1.50 & 1.83 & 4.89 & .10 & $-17.70-$ \\
\hline \multicolumn{2}{|c|}{ Maximum } & 6.77 & 15.90 & 11.68 & 18.53 & 3.18 & 9.70 & 99.60 & 21.30 & 13.50 \\
\hline
\end{tabular}

Hypothesis Test Summary

\begin{tabular}{|c|c|c|c|}
\hline & Null Hypothesis & Sig. & Decision \\
\hline 1 & $\begin{array}{l}\text { The distribution of } y \text { is nomal withene-Sample } \\
\text { mean } 1.92 \text { and standard deviationKolmogorov- } \\
2.050 . \\
\text { Smimov Test }\end{array}$ & $.068^{1}$ & $\begin{array}{l}\text { Retain the } \\
\text { null } \\
\text { hypothesis. }\end{array}$ \\
\hline
\end{tabular}

Asymptotic significances are displayed. The significance level is .05.

${ }^{1}$ Lilliefors Corrected

\begin{tabular}{ll|r|r|r} 
& & \multicolumn{3}{c}{ Model Summary $^{\text {d }}$} \\
Model & R & R Square & \multicolumn{1}{c}{$\begin{array}{c}\text { Adjusted R } \\
\text { Square }\end{array}$} & $\begin{array}{l}\text { Std. Error of } \\
\text { the Estimate }\end{array}$ \\
\hline 1 & $.706^{\mathrm{a}}$ & .498 & .480 & 1.47736 \\
\hline 2 & $.794^{\mathrm{b}}$ & .630 & .603 & 1.29161 \\
\hline 3 & $.836^{\mathrm{c}}$ & .699 & .665 & 1.18701 \\
\hline
\end{tabular}

a. Predictors: (Constant), $\mathrm{x} 8$

b. Predictors: (Constant), $\mathrm{x} 8, \mathrm{x} 4$ 
Taxes repercussion on FDI in UAE in light of recommendations of IMF

Dr/ Mosaad Mohamed Elgayish

c. Predictors: (Constant), x8, x4, x7

d. Dependent Variable: y

ANOVA $^{\mathrm{a}}$

\begin{tabular}{|c|c|c|c|c|c|c|}
\hline Model & & $\begin{array}{l}\text { Sum of } \\
\text { Squares }\end{array}$ & $\mathrm{df}$ & $\begin{array}{l}\text { Mean } \\
\text { Square }\end{array}$ & $\mathrm{F}$ & Sig. \\
\hline \multirow[t]{3}{*}{1} & Regression & 60.722 & 1 & 60.722 & 27.821 & $.000^{b}$ \\
\hline & Residual & 61.113 & 28 & 2.183 & & \\
\hline & Total & 121.835 & 29 & & & \\
\hline \multirow[t]{3}{*}{2} & Regression & 76.792 & 2 & 38.396 & 23.016 & $.000^{\mathrm{c}}$ \\
\hline & Residual & 45.043 & 27 & 1.668 & & \\
\hline & Total & 121.835 & 29 & & & \\
\hline \multirow[t]{3}{*}{3} & Regression & 85.201 & 3 & 28.400 & 20.157 & $.000^{\mathrm{d}}$ \\
\hline & Residual & 36.634 & 26 & 1.409 & & \\
\hline & Total & 121.835 & 29 & & & \\
\hline
\end{tabular}

a. Dependent Variable: y

b. Predictors: (Constant), $\mathrm{x} 8$

c. Predictors: (Constant), $\mathrm{x} 8, \mathrm{x} 4$

d. Predictors: (Constant), x8, x4, x7 


\begin{tabular}{|c|c|c|c|c|c|c|c|c|}
\hline \multirow[b]{3}{*}{ Model } & \multicolumn{8}{|c|}{ Coefficients ${ }^{\mathrm{a}}$} \\
\hline & & \multicolumn{2}{|c|}{$\begin{array}{l}\text { Unstandardized } \\
\text { Coefficients }\end{array}$} & \multirow{2}{*}{$\begin{array}{c}\text { Standardized } \\
\text { Coefficients } \\
\text { Beta }\end{array}$} & \multirow[b]{2}{*}{$\mathrm{t}$} & \multirow[b]{2}{*}{ Sig. } & \multicolumn{2}{|c|}{ Collinearity Statistics } \\
\hline & & $\mathrm{B}$ & Std. Error & & & & Tolerance & VIF \\
\hline \multirow[t]{2}{*}{1} & (Constant) & 2.503 & .292 & & 8.581 & .000 & & \\
\hline & $\mathrm{x} 8$ & .152 & .029 & .706 & 5.275 & .000 & 1.000 & 1.000 \\
\hline \multirow[t]{3}{*}{2} & (Constant) & $-1.774-$ & 1.401 & & $-1.266-$ & .216 & & \\
\hline & $\mathrm{x} 8$ & .118 & .028 & .546 & 4.269 & .000 & .837 & 1.194 \\
\hline & $x 4$ & 1.848 & .596 & .397 & 3.104 & .004 & .837 & 1.194 \\
\hline \multirow[t]{4}{*}{3} & (Constant) & $-.647-$ & 1.368 & & $-.473-$ & .640 & & \\
\hline & $\mathrm{x} 8$ & .164 & .032 & .762 & 5.181 & .000 & .535 & 1.870 \\
\hline & $x 4$ & 1.855 & .547 & .398 & 3.390 & .002 & .837 & 1.194 \\
\hline & $\mathrm{x} 7$ & $-.124-$ & .051 & $-.340-$ & $-2.443-$ & .022 & .595 & 1.680 \\
\hline
\end{tabular}

a. Dependent Variable: $\mathrm{y}$

\section{Reliability Statistics}

Cronbach's Alpha Based on

Cronbach's Alpha Standardized Items

$\mathrm{N}$ of Items

$.586 \quad .806$

\section{Excluded Variables ${ }^{a}$}

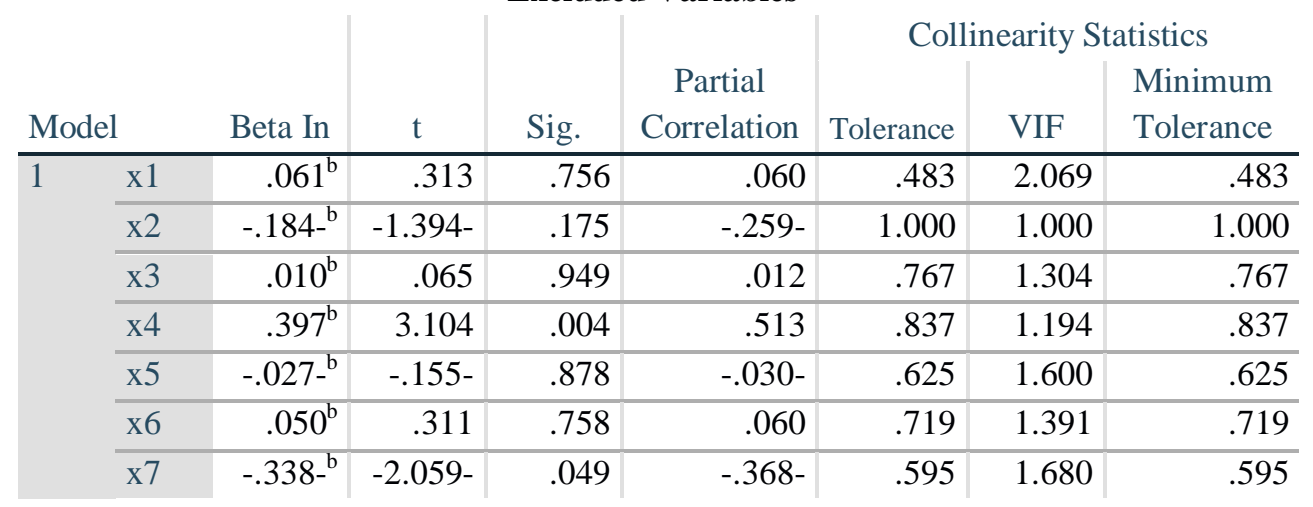


Taxes repercussion on FDI in UAE in light of recommendations of IMF

Dr/ Mosaad Mohamed Elgayish

\begin{tabular}{|r|r|r|r|r|r|r|r|}
\hline 2 & $.128^{\mathrm{c}}$ & .751 & .459 & .146 & .476 & 2.102 & .417 \\
\hline $\mathrm{x} 1$ & $-.124-^{\mathrm{c}}$ & $-1.048-$ & .304 & $-.201-$ & .970 & 1.031 & .812 \\
\hline $\mathrm{x} 3$ & $-.063-^{\mathrm{c}}$ & $-.456-$ & .653 & $-.089-$ & .744 & 1.343 & .700 \\
\hline $\mathrm{x} 5$ & $-.01-^{\mathrm{c}}$ & $-.114-$ & .910 & $-.022-$ & .625 & 1.601 & .553 \\
\hline $\mathrm{x} 6$ & $.141^{\mathrm{c}}$ & .999 & .327 & .192 & .690 & 1.448 & .580 \\
\hline $\mathrm{x} 7$ & $-.340-^{\mathrm{c}}$ & $-2.443-$ & .022 & $-.432-$ & .595 & 1.680 & .535 \\
\hline $\mathrm{x} 1$ & $.075^{\mathrm{d}}$ & .469 & .643 & .093 & .466 & 2.146 & .296 \\
\hline $\mathrm{x} 2$ & $.028^{\mathrm{d}}$ & .215 & .832 & .043 & .686 & 1.458 & .421 \\
\hline $\mathrm{x} 3$ & $-.098-^{\mathrm{d}}$ & $-.778-$ & .444 & $-.154-$ & .735 & 1.361 & .453 \\
\hline $\mathrm{x} 5$ & $-.041-^{\mathrm{d}}$ & $-.298-$ & .768 & $-.060-$ & .622 & 1.609 & .387 \\
\hline $\mathrm{x} 6$ & $.090^{\mathrm{d}}$ & .676 & .505 & .134 & .671 & 1.491 & .378 \\
\hline
\end{tabular}
a. Dependent Variable: y
b. Predictors in the Model: (Constant), $\mathrm{x} 8$
c. Predictors in the Model: (Constant), $x 8, x 4$
d. Predictors in the Model: (Constant), x8, x4, x7

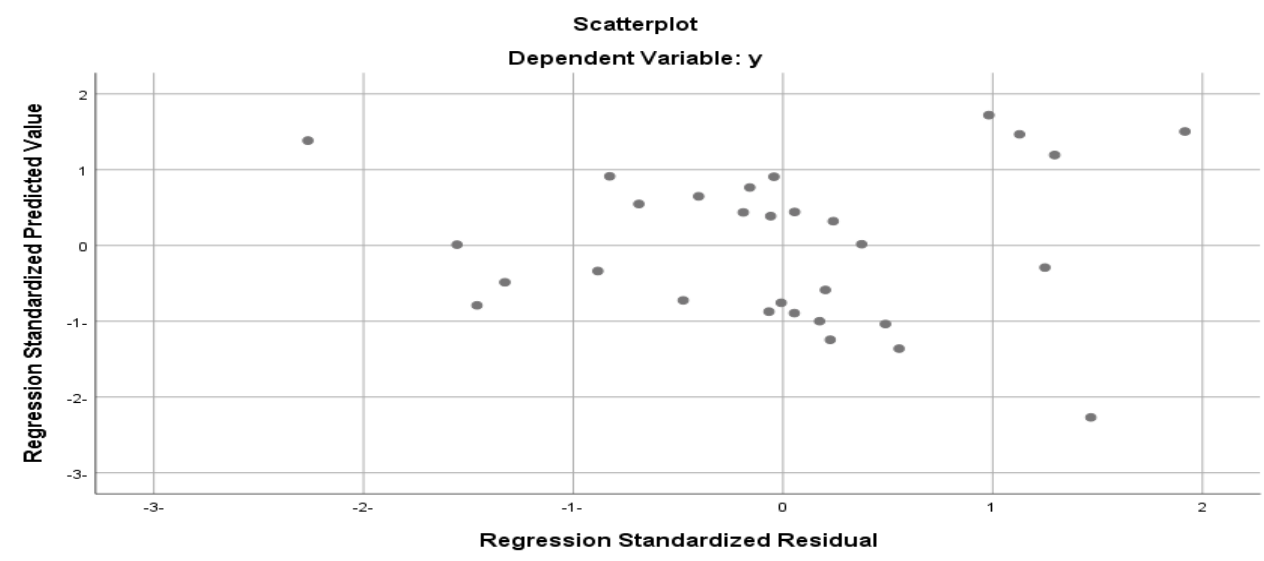

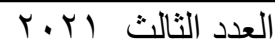




\begin{tabular}{|c|c|c|c|c|c|c|c|c|c|}
\hline \multirow[b]{3}{*}{$\begin{array}{l}\text { Mod } \\
\text { el }\end{array}$} & \multicolumn{9}{|c|}{ Model Summary ${ }^{d}$} \\
\hline & & & & Std. Error & & Cha & ge Statis & & \\
\hline & $\mathrm{R}$ & $\begin{array}{c}\mathrm{R} \\
\text { Square }\end{array}$ & $\begin{array}{l}\text { Adjusted R } \\
\text { Square }\end{array}$ & $\begin{array}{c}\text { of the } \\
\text { Estimate }\end{array}$ & $\begin{array}{l}\text { R Square } \\
\text { Change }\end{array}$ & $\begin{array}{c}\mathrm{F} \\
\text { Change }\end{array}$ & df1 & df2 & $\begin{array}{c}\text { Sig. F } \\
\text { Change }\end{array}$ \\
\hline 1 & $.706^{\mathrm{a}}$ & .498 & .480 & 1.47736 & .498 & 27.821 & 1 & 28 & .000 \\
\hline 2 & $.794^{\mathrm{b}}$ & .630 & .603 & 1.29161 & .132 & 9.633 & 1 & 27 & .004 \\
\hline 3 & $.836^{\mathrm{c}}$ & .699 & .665 & 1.18701 & .069 & 5.968 & 1 & 26 & .022 \\
\hline
\end{tabular}

a. Predictors: (Constant), x8

b. Predictors: (Constant), x8, x4

c. Predictors: (Constant), x8, x4, x7

d. Dependent Variable: y 